\title{
Potensi Tanaman Indonesia sebagai Antidiabetes melalui Mekanisme Penghambatan Enzim $\alpha$-glukosidase
}

\author{
Rinieta Sausan Margono ${ }^{1 *}$, Triyani Sumiati² \\ 'Fakultas Kedokteran Universitas Pembangunan Nasional“VETERAN" Jakarta \\ ${ }^{2}$ Farmasi Sekolah Tinggi Teknologi Industri dan Farmasi Bogor \\ *Korespondensi : sausannita@gmail.com
}

\begin{abstract}
ABSTRAK
Diabetes melitus adalah salah satu penyakit akibat gangguan metabolisme yang ditandai oleh keadaan hiperglikemia dan abnormalitas dalam metabolisme karbohidrat, lemak, dan protein. Salah satu cara untuk mengatasi hiperglikemia adalah dengan mengurangi jumlah glukosa yang dapat diserap tubuh dengan menekan proses pencernaan karbohidrat oleh inhibitor enzim $\alpha$-glukosidase. Terapi antidiabetes dapat dilakukan dengan menggunakan obat sintetik maupun menggunakan tanaman. Popularitas dan perkembangan obat tradisional tersebut semakin meningkat seiring dengan adanya kecendrungan masyarakat kembali ke alam. Indonesia merupakan negara yang kaya akan bahan-bahan alam hayati dan jenisnya sangat bervariasi terutama tumbuhan sehingga banyak peneliti yang tertarik untuk meneliti tumbuhan di negeri ini. Dalam tulisan ini dibahas mengenai mekanisme terapi antidiabetes melalui mekanisme $\alpha$-glukosidase dan mengeksplorasi potensi tanaman di Indonesia sebagai antidiabetes.
\end{abstract}

\section{Kata Kunci: Diabetes melitus, enzim $\alpha$-glukosidase, potensi, tanaman}

\begin{abstract}
Diabetes Mellitus is a disease caused by complications that are characterized by a state of hyperglycemia and abnormalities in migration, fat, and protein. One way to overcome hyperglycemia is to reduce the amount that the body can absorb by increasing the digestion process by the enzyme inhibitor $\alpha$-glucosidase. Antidiabetic therapy can be done using synthetic drugs using herbs. Popular and growing traditional medicine is increasing along with the tendency of people to return to nature. Indonesia is a country that is rich in natural biological materials and very diverse types of plants so that many researchers are interested in researching plants in this country. In this paper discusses antidiabetic therapy through changes in $\alpha$-glucosidase and discusses the potential of plants in Indonesia as antidiabetic.
\end{abstract}

\section{Keywords: Diabetes Melitus, $\alpha$-glucosidase enzyme, potency, plant}

\section{PENDAHULUAN}

Diabetes Melitus (DM) merupakan penyakit kronis yang masih menjadi masalah utama dalam dunia kesehatan di Indonesia. Penderita DM terus meningkat seiring dengan meningkatnya tingkat kemakmuran dan gaya hidup manusia. International Diabetes Federation (IDF) tahun 2019 mengatakan bahwa diperkirakan 463 juta orang menderita diabetes dan jumlah ini diproyeksikan mencapai 578 juta pada tahun 2030, dan 700 juta pada tahun 2045 (1). Negara Indonesia menempati urutan ke-6 negara dengan penderita diabetes melitus terbanyak setelah China, India, Amerika Serikat, Brazil, dan Meksiko yaitu berjumlah 10,3 juta orang (2).

Diabetes Melitus adalah gangguan metabolisme yang ditandai dengan hiperglikemia yang berhubungan dengan abnormalitas metabolisme karbohidrat, lemak, dan protein, yang disebabkan oleh penurunan sekresi insulin, atau penurunan sensitivitas insulin, atau keduanya (3). Penderita diabetes dalam keadaan normal memiliki kadar gula sebesar >200mg/dL, sedangkan dalam keadaan berpuasa 
memiliki kadar gula sebesar $>160 \mathrm{mg} / \mathrm{dL}$. Insulin dapat menghantarkan glukosa masuk ke dalam sel dengan bantuanGlucose Transporter 4 (GLUT 4) yang ada pada membran sel, kemudian glukosa akan dimetabolisme menjadi Adenin Triposfat (ATP). Jika insulin tidak ada atau berjumlah sedikit, maka glukosa tidak akan masuk ke dalam sel dan akan terus berada di aliran darah yang akan mengakibatkan keadaan hiperglikemia,sehingga diabetes seringkali muncul tanpa gejala (5). Gejala tipikal yang sering dirasakan penderita diabetes antara lain poliuria (sering buang air kecil), polidipsia (sering haus), dan polifagia (banyak makan/mudah lapar). Selain itu sering pula muncul keluhan penglihatan kabur, koordinasi gerak anggota tubuh terganggu, kesemutan pada tangan atau kaki, timbul gatal-gatal yang seringkali sangat mengganggu (pruritus), dan berat badan menurun tanpa sebab yang jelas (4).

Jika DM ini tidak ditangani secara cepat, dapat menyebabkan mikrovaskuler, makrovaskuler, neuropati dan komplikasi kronis(3). Berdasarkan American Diabetes Association (ADA) Guidelines, DM dapat menimbulkan banyak komplikasi seperti infeksi pada kulit, komplikasi mata berupa glaukoma, katarak, atau retinopati diabetik, neuropati diabetik, nefropati diabetik, dan stroke (6).

Penderita DM sebaiknya melaksanakan empat pilar pengelolaan diabetes Melitus yaitu edukasi, terapi gizi medis, latihan jasmani, dan intervensi farmakologis (7). Intervensi farmakologis dapat dilakukan dengan menghambat kerja enzim $\alpha$ glukosidase yang berfungsi mempercepat perombakan karbohidrat yang belum terserap (oligosakarida dan disakarida) menjadi monosakarida di dalam usus halus, sehingga asupan glukosa dari usus ke dalam darah dapat dikurangi. Senyawa aktif yang memiliki aktivitas seperti ini misalnya metformin, tiazolidindion, dan penghambat alfa-glukosidase (8).

Tingginya jumlah penderita diabetes di Indonesia telah mendorong upaya dilakukannya pengembangan obat antidiabetes, salah satunya berasal dari tumbuhan yang digunakan sebagai obat tradisional. Masyarakat pada umumnya menggunakan tanaman sebagai pengobatan diabetes karena efek samping yang lebih rendah dan biaya yang lebih murah. Beberapa tanaman obat terbukti sebagai salah satu sumber bagi bahan baku obat hiperglikemik, karena tanaman tersebut mempunyai senyawa-senyawa yang berkhasiat sebagai antihiperglikemik, diantaranya sambiloto (Andrographis paniculata Ness), johar (Cassia siamea Lamk), dandang gendis (Clinicanthus nutans Lindau), bawang putih (Allium sativum L.) dan cecendet (Physalis minima L.) (9).

\section{PATOFISIOLOGI DIABETES MELITUS Jenis Diabetes Melitus}

Penyakit Diabetes Melitus (DM) merupakan penyakit kronis gangguan metabolisme karbohidrat, lemak dan protein yang ditandai dengan tingginya kadar gula darah (9) akibat gangguan sekresi insulin oleh sel-sel $\beta$ Langerhans kelenjar pankreas, aksi insulin terhadap jaringan target yang mengakibatkan insensitivitas sel terhadap insulin, ataupun keduanya (10). Umumnya Diabetes Melitus diklasifikasikan menjadi 4 tipe yaitu:

\section{Diabetes Melitus Tipe 1}

Diabetes Melitus tipe 1 adalah penyakit gangguan metabolik yang ditandai oleh kenaikan kadar gula darah akibat destruksi (kerusakan) sel beta pankreas ( kelenjar ludah perut) karena suatu sebab tertentu yang menyebabkan produksi insulin tidak ada sama sekali sehingga penderita sangat memerlukan tambahan insulin dari luar (11).

\section{Diabetes Melitus Tipe 2}

Diabetes Melitus tipe 2 adalah penyakit gangguan metabolik yang ditandai oleh kenaikan kadar gula darah akibat penurunan sekresi insulin oleh sel beta pankreas dan ataufungsi insulin (resistensi insulin) (11).

\section{Diabetes Melitus tipe lain}

Diabetes Melitus tipe lain adalah penyakit gangguan metabolik yang ditandai oleh kenaikan kadar gula darah 
88 | Rinieta Sausan Margono et al., (Potensi Tanaman Indonesia Sebagai Antidiabetes...)

akibat defek genetik fungsi sel beta, defek genetik kerja insulin, penyakit eksokrin pankreas, endokrinopati, karena obat atau zat kimia, infeksi, sebab imunologi yang jarang, sindrom genetik lain yang berkaitan dengan $\mathrm{DM}(11)$

4. Diabetes Melitus tipe Gestasional

Diabetes Melitus tipe gestasional adalah penyakit gangguan metabolik yang ditandai oleh kenaikan kadar gula darah yang terjadi pada wanita hamil, biasanya terjadi pada usia 24 minggu masa kehamilan, dan setelah melahirkan kadar gula darah kembali normal (11).

\section{MEKANISME PENGHAMBATAN ENZIM GLUKOSOSIDASE}

Enzim alfa glukosidase merupakan golongan enzim ekso alfa glukosida yang bekerja menghidrolisis ikatan 1,4-glikosik dan melepaskan D-glukosa dari hasil akhir substrat. Polisakarida yang merupakan salah satu sumber gizi akan dipecah menjadi oligosakarida oleh a-amilase di air liur dan pankreas. Produk hidrolisis aamilase akan diteruskan sampai di usus kecil. Disakarida seperti maltosa dengan ikatan a--1,4-glikosida, isomaltosa dengan a-1,6-glikosida dan sukrosa dengan a-1,2glikosida akan dipecah menjadi monosakarida oleh a-glukosidase di membran brush border usus kecil (12). Monosakarida seperti glukosa yang telah terbentuk akan diabsorbsi oleh epitelium intestinal dan masuk ke peredaran darah (13) sehingga gula darah akan meningkat di dalam tubuh. Mekanisme perubahan gula oleh enzim alfa glukosidase dapat dilihat pada gambar berikut :
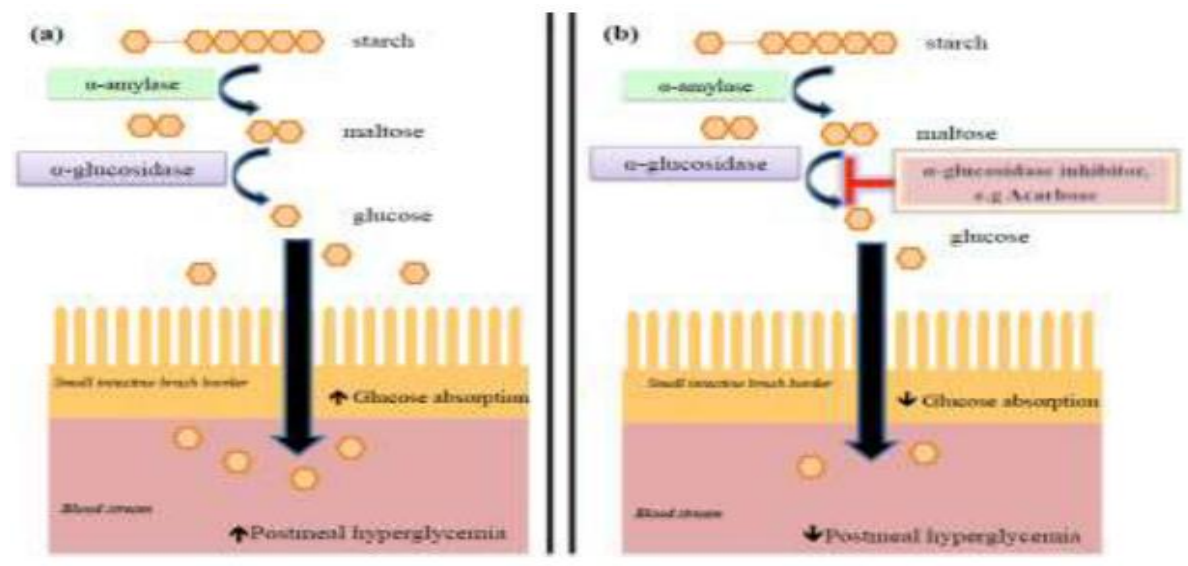

\section{Gambar 1. Mekanisme hidrolisis karbohidrat oleh enzim $\alpha$-glukosidase(a) dan inhibisi enzim(b) (14).}

Terdapat tiga jenis obat antidiabetes oral yang merupakan golongan penghambat aktivitas enzim $\alpha$-glukosidase yaitu akarbosa, magnitol, dan voglibose. Diantara ketiga obat tersebut, akarbosa adalah obat yang paling umum digunakan di Indonesia (14). $\alpha$-glukosidase dapat membantu mengatasi kondisi dari hiperglikemia karena jumlah dari monosakarida yang diserap oleh usus menjadi berkurang(15).

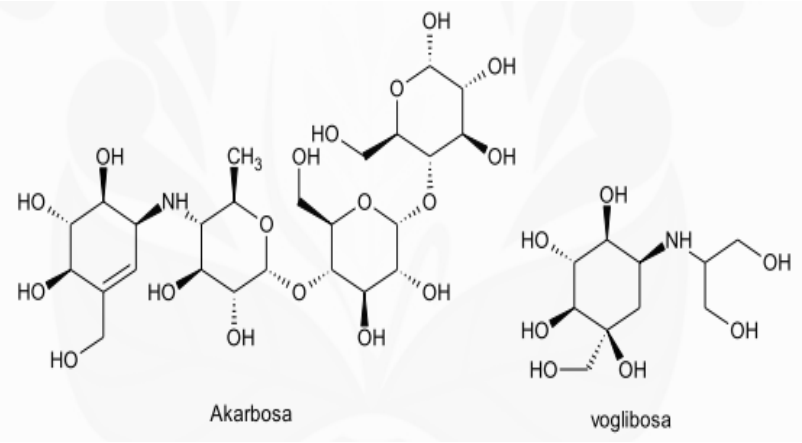


89 | Rinieta Sausan Margono et al., (Potensi Tanaman Indonesia Sebagai Antidiabetes...)

\section{Gambar 2. Struktur Akarbosa dan Voglibosa}

Akarbose dilaporkan Gown (2006 dalam (16)) adalah senyawa inhibitor $\alpha$ glukosidase yang telah sukses dikomersilkan dan merupakan suatu pseudo-oligosakarida yang memiliki struktur mirip glukosa. Mekanisme kerja inhibitor enzim $\alpha$-glukosidase pada isolat tanaman duwet (Syzygium cumini L. Skeels) diduga sama dengan mekanisme penghambatan oleh akarbosa yang menghambat secara kompetitif enzim $\alpha$ glukosidase di dalam lumen usus halus(17). Penghambatan secara kompetitif terjadi karena inhibitor mampu berikatan dengan pusat aktif enzim kemudian berkompetisi dengan substrat sehingga tidak terbentuk produk.(18).

Pengukuran daya inhibisi dilakukan secara in vitroberdasarkan absorbansi pnitrofenol yang dihasilkan dari hidrolisis substrat ( $\mathrm{p}$-nitrofenil $\alpha$-D-glukopiranosida) menjadi p-nitrofenol (berwarna kuning) dan D-glukosa oleh enzim $\alpha$ - glukosidase. Intensitas warna kuning p- nitrofenol yang dihasilkan akan mempengaruhi nilai absorbansi yang diperoleh. Semakin besar aktivitas inhibisi ekstrak maka jumlah pnitrofenol yang dihasilkan semakin sedikit sehingga intensitas warna kuning akan berkurang. Senyawa yang dapat menghambat enzim tersebut menunjukkan indikasi bahwa senyawa tersebut berpotensi sebagai antidiabetes. (19).

\section{POTENSI TANAMAN YANG MENGINHIBISI A-GLUKOSIDASE}

Aktivitas antidiabetes melalui mekanisme inhibisi $\alpha$-glukosidase, dapat ditentukan melalui pengukuran kadar glukosa darah setelah pemberian ekstrak tanaman dan melalui pengukuran nilai $\mathrm{IC}_{5}$ 0. Nilai IC50 merupakan nilai yang menunjukkan konsentrasi ekstrak yang menyebabkan penghambatan sebesar $50 \%$ terhadap aktivitas enzim $\alpha$-glukosidase. Potensi tanaman di Indonesia yang mempunyai aktivitas inhibisi $\alpha$-glukosidase dapat dilihat pada Tabel 1 .

Tabel 1. Potensi tanaman di Indonesia yang mempunyai aktivitas $\alpha$-glukosidase

\begin{tabular}{|c|c|c|}
\hline \multirow{3}{*}{$\begin{array}{l}\text { Sumber tanaman } \\
\text { Kulit Batang Kayu Manis Padang } \\
\text { (C.burmannii) }\end{array}$} & \multirow{2}{*}{$\begin{array}{l}\text { Metode Ekstraksi } \\
\text { Maserasi menggunakan air }\end{array}$} & \multirow{2}{*}{$\begin{array}{l}\text { Pustaka } \\
(19)\end{array}$} \\
\hline & & \\
\hline & Maserasi menggunakan etanol & (19) \\
\hline $\begin{array}{l}\text { Beras Ketan Hitam } \\
\text { (Oryza satival. Var glutinosa) }\end{array}$ & Maserasi menggunakan air & (9) \\
\hline $\begin{array}{l}\text { Daun Singawalang (Petiveria alliacea } \\
\text { L.) }\end{array}$ & Maserasi menggunakan etanol $96 \%$ & (20) \\
\hline 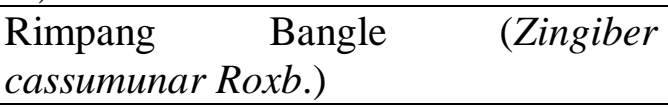 & $\begin{array}{l}\text { Maserasi menggunakan pelarut } \\
\text { etanol }\end{array}$ & $(21)$ \\
\hline $\begin{array}{l}\text { Buah okra (Abelmoschus esculentus } \\
\text { (L.) Moench) }\end{array}$ & $\begin{array}{l}\text { Maserasi menggunakan pelarut } \\
\text { etanol } 96 \% \text { dilanjut perendaman air } \\
\text { suling } 4 \text { jam }\end{array}$ & $(22)$ \\
\hline Kulitbuahkakao (Theobroma cacao L.) & $\begin{array}{l}\text { Maserasimenggunakan pelarutaseton } \\
80 \%\end{array}$ & (23) \\
\hline Daun Murbei Putih (Morus alba L.) & $\begin{array}{l}\text { Maserasi menggunakan etanol } 70 \% \\
\text { lalu dipartisi dengan etil asetat }\end{array}$ & (24) \\
\hline $\begin{array}{l}\text { Daun jati belanda (Guazuma ulmifolia } \\
\text { Lam.) }\end{array}$ & $\begin{array}{l}\text { Maserasi bertingkat dengan ekstrak } \\
\text { metanol }\end{array}$ & $(25)$ \\
\hline Daun Cryptocarya densiflora Blume & Fraksi etil asetat dari ekstrak metanol & $(26)$ \\
\hline $\begin{array}{l}\text { Kulit buah maja (Aegle marmelos (L.) } \\
\text { Correa }\end{array}$ & Maserasi dengan etil asetat & $(27)$ \\
\hline $\begin{array}{l}\text { Tumbuhan bungur (Lagerstroemia } \\
\text { loudonii T.\& } B . \text { ) }\end{array}$ & Maserasi dengan pelarut etanol $96 \%$ & $(28)$ \\
\hline
\end{tabular}


90 | Rinieta Sausan Margono et al., (Potensi Tanaman Indonesia Sebagai Antidiabetes...)

\begin{tabular}{|l|l|l|}
\hline $\begin{array}{l}\text { Petai Cina (Leucaena leucocephala } \\
\text { (Lam).De Wit) }\end{array}$ & Maserasi dengan pelarut etanol 96\% & (3) \\
\hline Daun buni (Antidesma bunius L.) & $\begin{array}{l}\text { Fraksi gabungan (etil asetat:metanol } \\
(60: 140) ;(40: 160) ;(20: 180) ;(0: 200))\end{array}$ & (29) \\
\hline $\begin{array}{l}\text { Daun Kenitu (Chrysophyllum cainito } \\
\text { L.) }\end{array}$ & Maserasi menggunakan etanol 70\% & $(30)$ \\
\hline $\begin{array}{l}\text { Temulawak (Curcuma xanthorrhiza } \\
\text { RoxB.) }\end{array}$ & Maserasi menggunakan etanol 96\% & $(31)$ \\
\hline $\begin{array}{l}\text { Biji buah Nangka (Artocarpus } \\
\text { heterophyllus L.) }\end{array}$ & Maserasi menggunakan etanol 70\% & $(32)$ \\
\hline $\begin{array}{l}\text { Biji Lamtoro Gung (Leucaena } \\
\text { leucocephala) }\end{array}$ & Dilarutkan dalam air & $(33)$ \\
\hline
\end{tabular}

Dari berbagai hasil penelitian mengenai potensi tanaman Indonesia yang mempunyai aktivitas antidiabetes diperoleh bahwa ekstrak kair kayu manis dapat menurunkan kadar glukosa darah sebesar 94,51\% dan ekstrak etanol kayu manis sebesar 94,88\% (19); penurunan kadar glukosa darah oleh ekstrak air beras ketan hitam sebesar 57,57 penurunan kadar glukosa darah oleh \% (9); penurunan kadar glukosa darah oleh ekstrak etanol daun singawang sebesar $1,65 \%$ dan ekstrak air daun singawang sebesar $6,25 \% \quad(20)$; penurunan kadar glukosa darah oleh ekstrak etanol rimpang bangle sebesar 50,28\% dan nilai $\mathrm{IC}_{5} 0_{\text {n }}$ sebesar 98,31 ppm (21); penurunan kadar glukosa darah oleh ekstrak okra sebesar 50\% dengan nilai $\mathrm{IC}_{5} 0$ sebesar 98,31ppm (22); nilai $\mathrm{IC}_{5}$ o ekstrak kulit batang kakao sebesar 712,86 (23); nilai $\mathrm{IC}_{5}{ }_{0}$ ekstrak etanol daun murbei putih sebesar $171 \mathrm{ppm}$ (24); penurunan kadar glukosa darah oleh ekstrak metanol daun jati belanda sebesar $5,213 \%$ dan nilai $\mathrm{IC}_{5} 0 \quad$ sebesar 563,724 ppm (25); penurunan kadar glukosa darah oleh ekstrak etil asetat daun cryptocaria densiflora sebesar $58,7 \%$ dan nilai $\mathrm{IC}_{5}$ o sebesar 93,32 ppm (26); nilai $\mathrm{IC}_{5}$ o ekstrak etanol tumbuhan bungur sebesar 79,48\% (28); penurunan kadar glukosa darah oleh ekstrak kulit buah maja sebesar 66,30\% (27); nilai $\mathrm{IC}_{5}$ o ekstrak etanol petai cina sebeasar 33,35 ppm (3); nilai $\mathrm{IC}_{5}$ o ekstrak etil asetat:metanol daun buni sebesar 4,79 ppm (29); nilai $\mathrm{IC}_{5}$ o ekstrak etanol daun kenitu sebesar 4,9\% (30); nilai $\mathrm{IC}_{5}$ o ekstrak etanol temulawak sebesar 333,3 ppm (31); penurunan kadar glukosa darah oleh ekstrak etanol biji buah nangka sebesar 62,39\%
(32) dan penurunan kadar glukosa darah oleh ekstrak etanol biji lamtoro gung sebesar $61 \%$. Menurut penelitian yang telah dilakukan oleh (Loranza, B 2012) bahwa dengan fraksi gabungan (etilasetat:metanol (60:140); (40:160); (20:180); (0:200)) memiliki nilai $\mathrm{IC}_{5}$ o 4,7863 ppm (nilai terendah) yang mengandung senyawa golongan flavonoid. Semakin kecil nilai $\mathrm{IC}_{5} 0$ maka semakin besar aktivitas inhibisinya dalam mekanisme penghambatan aktivitas $\alpha$-glukosidase.

\section{SIMPULAN}

Dari hasil penelusuran pustaka diperoleh bahwa obat herbal dari tanaman di Indonesia mempunyai potensi sebagai antidiabetes. Untuk kedepannya agar dapat lebih dimanfaatkan secara maksimal maka perlu dipelajari dan dikembangkan hingga mendapatkan hasil yang optimum dalam menghambat kerja enzim $\alpha$-Glukosidase sebagai obat antidiabetes yang lebih aman dikonsumsi di masa yang akan datang.

\section{DAFTAR PUSTAKA}

[1] IIDF. IDF Diabetes Atlas 2019 [Internet]. International Diabetes Federation. 2019. 1 p. (http://www.idf.org/aboutdiabetes/factsfigures, diakses tanggal 28 januari 2020)

[2] IDF (International Diabetes Federation). Eighth edition 2017 [Internet]. IDF Diabetes Atlas, 8th edition. 2017. 1$150 \quad$ p. $\quad$ (http://www file:///Users/ximeneacarballo/, diakses tanggal 28 januari 2020) 
91 | Rinieta Sausan Margono et al., (Potensi Tanaman Indonesia Sebagai Antidiabetes...)

[3] Rachmatiah T, Nurvita H, D RT. Potensi Antidiabetes Pada Tumbuhan Petai Cina ( Leucaena leucocephala ( Lam ). De Wit ). 2015;25(1):115-8.

[4] Inayati, Immah; Farida H. Sistem Pakar Deteksi Penyakit Diabetes Melitus (DM) Dini Berbasis Android. J Link. 2016;25(2):10-5.

[5] Wahyu N and Nurul Wahyu S. Senam Diabetes Melitus..., , Fakultas Ilmu Kesehatan,UMP, 2019. 2019;8-23.

[6]Carediabetes M. Updates to the Standards of Medical Care in Diabetes. Diabetes Care. 2018;41(9):2045-7.

[7] Diabetes VII, In C. Standards of medical care in diabetes. Diabetes Care. 2011;34(SUPPL.1).

[8] Dan P, Diabetes P, Tipe M. Perkumpulan Endokrinologi Indonesia Perrkeni Konsensus. 2015.

[9] Iryani I, Iswendi I, dan Katrina IT, Uji Aktivitas Anti Diabetes Melitus Senyawa Metabolit Sekunder Fraksi Air Dari Beras Ketan Hitam ( Oryza sativa L. Var glutinosa) pada mencit putih, Berk Ilmu Bid MIPA. 2017;18(01):54-60.

[10] Fitri R, Aktivitas Inhibitor $\alpha$ GlukosidaseIsolat Kapang Endofit Duwet (Syzygium cumini (L.) Skeels). J Chem Inf Model. 2013;53(9):168999.

[11] Ri DK. IDN_D1_Diabetes guidlines.pdf. 2008. p. 1.

[12] Kishikawa Y, Shinohara H, Maeda K, Nakamura Y, Wiegand S, Kita R. Temperature dependence of thermal diffusion for aqueous solutions of monosaccharides, oligosaccharides, and polysaccharides. Phys Chem Chem Phys. 2012;14(29):10147-53.

[14] Astriningtyas glucosidase S. Search for $\alpha$ Indonesian indigenous plants. Hokkaido Univ. 2015.

[15] Early Febrinda A, Astawan M, et al. Kapasitas Antioksidan Dan Inhibitor Alfa Glukosidase Ekstrak Umbi Bawang Dayak. J Teknol dan Ind Pangan. 2013;24(2):161-7.

[16] Pujiyanto S. Kajian Inhibitor $\alpha$ Glukosidase Aktinomisete Endofit Asal Brotowali (Tinospora crispa). Inst Pertan Bogor. 2012;66:37-9.

[17] Fatin N, Pujiyanto S, Biologi D, Sains F, Diponegoro U. Uji Aktivitas Inhibisi $\alpha$-Glukosidase Isolat Bakteri Endofit Tanaman Duwet (Syzygium cumini L. Skeels) Sebagai Sumber Alternatif Antidiabetes. Bioma Berk Ilm Biol. 2018;20(2):165-9.

[18] Mardiah E. Mekanisme Inhibisi Enzim Polifenol Oksidase Pada Sari Buah Markisa Dengan Sistein dan asam Askorbat. 2011;4(2):32-7.

[19] Anggriawan MB, Roswiem AP, Nurcholis DW. Potensi Ekstrak Air Dan Etanol Kulit Batang Kayu Manis Padang (Cinnamomum Burmanii). J Kedokt Yars. 2017;23(2):91-102.

[20] Elis Susilawati1, I Ketut Adnyana2 NF, 1SekolahYuniarto, A., \& Selifiana, N. (2018). Aktivitas Inhibisi Enzim Alfa-glukosidase dari Ekstrak Rimpang Bangle (Zingiber cassumunar Roxb.) secara In vitro. 
92 | Rinieta Sausan Margono et al., (Potensi Tanaman Indonesia Sebagai Antidiabetes...)

Media Pharmaceutica Indonesiana (MPI), 2(1) 22. https://doi.org/10.24123/mpi.v2i1.1299 . (konstanta tes toleransi insulin). Nilai K. 2016;13(02):182-91.

[21] Yuniarto A, Selifiana N. Aktivitas Inhibisi Enzim Alfa-glukosidase dari Ekstrak Rimpang Bangle (Zingiber cassumunar Roxb.) secara In vitro. Media Pharm Indones. 2018;2(1):22.

[22] Riyanti S, Ratnawati J, Aprilianti S. Potensi buah okra (Abelmoschus esculentus (L.) Moench) sebagai inhibitor alfa-glukosidase. Kartika J Ilm Farm. 2019;6(1):6.

[23] Chusniasih D. Eksplorasi Potensi Ekstrak Aseton Kulit Buah Kakao ( Theobroma cacao L .) Sebagai Inhibitor $\alpha$-Glukosidase . Jurnal Farmasi Malahayati. 2019;2(1):58-66.

[24] Balqis SH. Potensi Ekstrak Etanol Daun Murbei Putih ( Morus alba L .) sebagai Inhibitor Enzim $\alpha$ Glukosidase. ResearchGate. 2018;(May).

[25] Rachmi FI. Potensi Ekstrak Daun Jati Belanda (Guazuma ulmifolia Lam.). Sebagai Antidiabetes dan Antioksidan: Metode Penghambatan Enzim $\alpha$ Glukosidase dan DPPH In Vitro, Skripsi Fakultas Farmasi Univ Jember. 2016,

[26] Ariani, Nurul; Ratna Irma ; Kurniadewi F. Jurnal Riset Sains dan Kimia Terapan. J Ris Sains dan Kim Terap [Internet]. 2019;8(1):14-20. Available from: http://journal.unj.ac.id/unj/index.php/jr skt.

[27] Siama, Yustina; Alam, Gemini ; Wahyudin E. Uji Aktivitas Hipoglikemik Ekstrak Kulit Buah Maja ( Aegle marmelos ( L .) Correa Sebagai inhibitor Alfa Glukosidase, Fakultas Farmasi Univ.Hasanudin
Makasar.(http://pasca.unhas.ac.id/ diakses pada tanggal 28 Januari 2020)

[28] Riyanti S, Ratnawati J, Shaleh MI, Suganda AG. Potensi Kulit Batang Bungur (Lagerstroemia loudonii Binn.) Sebagai Herbal Antidiabetes dengan Mekanisme Penghambat Alfaglukosidase. Talent Conf Ser Trop Med. 2018;1(3):117-20.

[29] Loranza B. Uji Penghambatan Aktivitas Enzim Alfa-glukosidase dan Identifikasi Golongan Senyawa Kimia dari Fraksi Teraktif Daun Buni (Antidesma bunius L.). Skripsi Fak Mat dan Ilmu Pengetahuan Progr Stud Sarj Farm Depok. 2012.

[30] Zuhro F, Puspitasari E, Muslichah S, Hidayat MA. Aktivitas Inhibitor $\alpha$ Glukosidase Ekstrak Etanol Daun Kenitu (Chrysophyllum cainito L.) ( $\alpha$ Glucosidase Inhibitor Activity of Ethanol Extract Kenitu Leaves (Chrysophyllum cainito L.)). 2016;4(1):1-7.

(https://jurnal.unej.ac.id/index.php/JPK /article/view/2434 diakses tanggal 29 januari2020)

[31] Nurcholis W, Ambarsari L, Permasku GIA, Latifah K. Analisis Kandungan Kurkuminoid dan Penghambatan $\alpha-$ Glukosidase dari Ekstrak Beberapa Aksesi Temulawak ( Curcuma xanthorrhiza RoxB.). ResearchGate.2015;13(2):229-34.

[32] Rachmania RA, Efendi K, Atmojo TT. Potensi Biji Buah Nangka ( Artocarpus heterophyllus L .) Dalam Menghambat Reseptoe Alfa Glukosidase Pada Tikus Diabetes melitus Gestasional Yang terinduksi Streptozotosin Secara In Vivo dan In Silico. Prosiding Kolokium. 2018;1(1)18-30. 